\title{
Changes in plasma testosterone, thyroxine and triiodothyronine in relation to sperm production and remex moult in domestic ganders
}

\author{
M Zeman $1^{*}$, J Košutzký 2, Ĺ Miček 2, A Lengyel 2 \\ ${ }^{1}$ Slovak Academy of Sciences, Institute of Animal Physiology, 90028 Ivanka pri Dunaji; \\ 2 Poultry Research and Production Institute, 90028 Ivanka pri Dunaji, Czechoslovakia
}

(Received 28 November 1989; accepted 31 May 1990)

\begin{abstract}
Summary - Changes in plasma testosterone $(T)$, thyroxine $\left(T_{4}\right)$, triiodothyronine $\left(T_{3}\right)$, semen output and remex moult were studied in domestic ganders. A bimodal pattern in both plasma $T$ and sperm concentration was observed during the annual cycle. Ganders started to produce semen at the end of January; maximum semen volume $(0.32 \pm 0.04 \mathrm{ml})$ and sperm concentration $(148 \pm 38 \mathrm{x}$ $10^{3} / \mathrm{mm}^{3}$ ) were reached in March and a marked decrease was observed after mid-April, when the moult of the remiges began. Plasma $T_{3}$ levels peaked in February $\left(9.7 \pm 0.6 \mathrm{nmol}^{-1} \mathrm{I}^{-1}\right)$ and this peak coincided with maximum $T$ concentrations $\left(9.8-10.4 \mathrm{nmol}^{-1}\right)$. Elevated levels of $T_{4}$ were found from late February until mid-April (31.0-33.6 nmol.1-1). Plasma $T$ concentration was low at all stages of remex moult and regrowth. Decreased $\mathrm{T}_{4}$ levels were found in ganders during remex regrowth from the "brush" to half of the full primary growth stage. Higher plasma $T_{4}$ levels were found before and after this stage of the moult. A reverse pattern was observed for $T_{3}$ concentrations.
\end{abstract}

testosterone / thyroxine / sperm concentration / semen volume / moult / gander

Résumé - Testostérone, thyroxine et triiodothyronine plasmatiques en relation avec la production spermatique et la mue chez le jars domestique. Les changements de concentration plasmatique de testostérone $(T)$, de thyroxine $\left(T_{4}\right)$ et de triodothyronine $\left(T_{3}\right)$ ainsi que la production de spermatozoïdes et la mue des rémiges ont été étudiés chez le jars domestique. La sécrétion de $T$ et la concentration des éjaculats en spermatozoïdes présente un profil bimodal au cours de l'année. Les premiers spermatozoïdes sont observés à la fin du mois de janvier, leur production est maximale en mars ( $57 \pm 17 \times 10^{6}$ /éjaculat) puis diminue en avril au moment où les rémiges commencent à tomber. La concentration de $T_{3}$ est maximale $(9,7 \pm 0,6$ nmol/l) en même temps que celle de $T$ $(9,8 \pm 10,4 \mathrm{nmol} / \mathrm{l})$. La concentration en $T_{4}$ augmente de la fin février à la mi-avril (31-34 nmol/I). Les concentrations plasmatiques de $T$ sont faibles pendant la mue des rémiges; celles de $T_{4}$ passent par un minimum aux stades 4-5 de la mue et présentent un profil inverse de celui des concentrations plasmatiques de $T_{3}$.

testostérone / thyroxine / concentration spermatique / mue / jars

\footnotetext{
* Correspondence and reprints
} 


\section{INTRODUCTION}

The domestic goose shows the seasonal pattern of reproductive activity which its wild ancestor, the Graylag goose (Anser anser) evolved in adapting to seasonal changes of environmental conditions. This reproductive strategy is convenient in the traditional extensive breeding conditions characterized by natural incubation of eggs and parental care. However, the introduction of large-scale goose production requires the artificial incubation of eggs and a substantial increase of reproductive performance, particularly an extension of the reproductive period in the annual cycle. Endocrine mechanisms control the development of reproductive capacity, and their study seems to be important in improving the reproductive performance in this species of waterfowl.

In many avian species of mid and high latitudes, day length is the major environmental trigger in the initiation and synchronization of annual reproductive cycles. Increasing day length in the spring induces acceleration of gonadotropin secretion, and this precedes and stimulates vernal increase in the gonadal activity of birds (Farner and Gwinner, 1980; Farner and Wingfield, 1980). Reproductive activity is terminated by the development of long-day refractoriness which results in an inhibition of gonadotropin-releasing hormone synthesis and gonadal regression under long photoperiod (Nicholls et al, 1988). The mechanisms involved in the development of long day refractoriness are still unclear but the role of interactions between seasonally elevated sex hormones and thyroid hormones, and between gonadotropins and prolactin have been suggested (Assenmacher and Jallageas, 1980; Follett and Nicholls, 1984; Nicholls et al, 1988; Dawson, 1989). Geese are the only species of poultry regularly used in breeding for several seasons. A study of endocrine control of seasonal breeding could improve their management and the benefits of their breeding. However, such studies are rare in geese (Košutzký et al, 1982; Lazar, 1983; Péczely et al, 1985; Zeman et al, 1987) and most data about the endocrine control of reproduction in waterfowl come from studies on ducks (Jallageas and Assenmacher, 1974; Paulke and Haase, 1978). The objective of this study was to establish the relationship between changes in semen production and plasma testosterone concentration and to evaluate the relationships among semen output, primary remex moult and plasma concentrations of testosterone $(T)$, thyroxine $\left(T_{4}\right)$ and triiodothyronine $\left(T_{3}\right)$ in ganders.

\section{MATERIALS AND METHODS}

Ganders of a parent line of broiler breeder geese Ivages were used. They were hatched in March and studied in the following year, ie in both trials during their first reproductive season. The birds were housed in groups of 10 in pens with a slatted floor $(2.5 \times 2 \mathrm{~m})$ and an open concrete yard $(2 \times 3 \mathrm{~m})$ supplied with a trough containing running water $(2 \times 1.5 \mathrm{~m})$. A complete goose feed $(18.2 \%$ crude protein and 10.46 MJ metabolizable energy $/ \mathrm{kg}$ ) was provided.

\section{Experiment I}

Thirty ganders were exposed from 15 October to 20 December to a short photoperiod of $8 \mathrm{~h}$ of light and $16 \mathrm{~h}$ of darkness (LD 8:16) and restricted feed intake (180 $\mathrm{g}$ of feed per gander per d). From 20 December the feed was provided ad libitum and day length was increased gradually by artificial light (incandescent $100 \mathrm{~W}$ bulbs providing a light intensity of $10-50 \mathrm{~lx}$ at the level of the birds' heads) to a regime of LD 12:12 at the end of January. This light-dark cycle was held until 21 March and then the ganders were exposed to naturally increasing day length $\left(47^{\circ} 18^{\prime}\right.$ $\left.\mathrm{N}, 17^{\circ} 13^{\prime} \mathrm{E}\right)$. 
Blood and semen samples were taken at monthly intervals in the first 10 days of each month at the same time of day (between 8.00$10.00 \mathrm{~h}$ ). The semen was collected by dorsoabdominal massage. Semen volume was determined indirectly $(1 \mathrm{ml}=1 \mathrm{~g})$ by weighing (Williams and de Reviers, 1981) and sperm concentration by a haemocytometer. Blood was taken from the wing vein immediately (within $1 \mathrm{~min}$ ) after semen collection because this treatment did not significantly affect plasma testosterone concentration (Zeman, unpublished results). Heparinized blood was centrifuged at $2500 \mathrm{~g}$ for $10 \mathrm{~min}$; the plasma was removed and stored at $-20^{\circ} \mathrm{C}$ until assayed for testosterone.

\section{Experiment II}

Another $\mathbf{3 0}$ ganders were kept during the next year under the same management conditions as trial I, only the short photoperiod LD 8:16 lasted from 15 November to 10 January. Blood and semen were collected more frequently (2-3 weeks) during the reproductive season (January-June) in the same manner as in Experiment 1. The semen volume and sperm concentration were determined.

The concentrations of hormones were measured by radioimmunoassay. Thyroxine and triiodothyronine were estimated from unextracted plasma using commercial RIA-kits (Institute of Radioecology and Nuclear Technology Application, Košice, Czechoslovakia). Testosterone was determined by direct RIA with 125I tracer (Zeman et al, 1986). Standards in all 3 methods were made up in gander's plasma from which endogenous steroids and thyroid hormones were removed (Abraham, 1977).

At the end of the reproductive season the moult and the replacement of primary remiges were recorded according to Herremans (1986). A 10-step scale was used for the determination of the stages of remex moult in which $0=$ old $(1$ week before a drop), $1=$ dropped, $2=$ pin, $3=$ brush, and 4-10 = tenths of the full-grown length. Under this system, each bird was individually examined at 2-3-d intervals and a moult score of 1-10 was given for the 1st, 5 th and 10 th primaries. The global score was a mean from these 3 primaries. In most cases all primaries were in the same stage of moult, as is usual in Anseriformes.
Experimental values were analyzed by 2-way analysis of variance as a randomized complete block design (Sokal and Rohlf, 1969) with the ages at the respective stages of feather moult as the fixed treatment effects and the individuals constituting the randomly chosen blocks. Levels of significance were determined by Duncan's multiple range test.

\section{RESULTS}

\section{Experiment I}

A bimodal pattern of plasma testosterone concentration was found in ganders submitted to a modified light regime during the annual cycle (fig 1). High plasma $T$ levels were determined in December and January. Thereafter the concentration decreased dramatically and low levels were found from March to July. The second an-

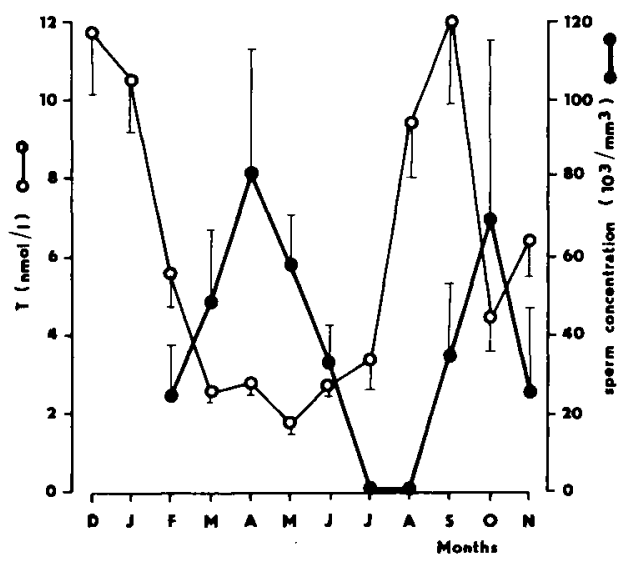

Fig 1. Changes of plasma testosterone levels and spermatozoa concentration in ganders; $M \pm$ SEM, $n=30$. Photoperiod LD 8:16 was applied from 15 October to 20 December, and was then gradually increased to LD 12:12 at the end of January. LD 12:12 was held until 21 March and then birds were exposed to a natural day length. 
nual peak of concentration of this androgen was observed during August and September, while low levels were recorded in October and November.

Sperm concentration also showed a bimodal pattern during the annual cycle of ganders. Spermatozoa were found at first in January and maximum sperm concentration was determined at the beginning of April. After this peak, sperm concentration decreased and no spermatozoa were found in July and August. A second, autumnal, reproductive period lasted from September to November and the peak of sperm concentration was found in October. The changes in testosterone levels preceded those in sperm production by about 2-3 months.

\section{Experiment II}

Concentrations of plasma $T$ were low in December and maximum concentrations were found in January and mid-February (fig 2). Thereafter, concentrations decreased $(P<0.05)$ and minimal levels were found in mid-May. The increase in plasma $T$ was followed by a rise in plasma $\mathrm{T}_{3}$ levels (fig 2) with maximum values at the beginning of February. Plasma $T_{4}$ increased from February to mid-March and was high until May. The decrease of plasma testosterone concentration and the increase in the $\mathrm{T}_{4}$ levels preceded a drop in semen quality and primary moult. The marked decline in semen volume and sperm concentration was accompanied by the onset of primary moult in a group of ganders (fig 3). Individual birds ceased to produce semen a week before the primaries were dropped. The sequence of remex moult was ascendant (from the apex of the wing towards the body) and the primaries dropped from both wings almost simultaneously in 1-2 d, even though some vari- ability in the temporal pattern of remex moult was observed. The moult and replacement of remiges lasted approximately 6-7 wk. During this period the ganders did not produce spermatozoa and their copulatory organs had regressed. The moult of contour-feathers occurred earlier than that of the primaries; however, it was not evaluated in detail.

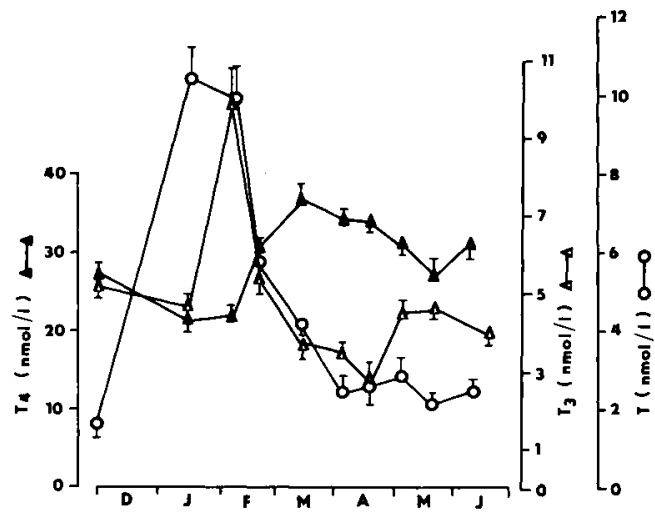

Fig 2. Changes of plasma $T, T_{3}$ and $T_{4}$ in ganders; $M \pm$ SEM, $n=30$. Photoperiod LD 8:16 was applied from 15 November to 10 January. Subsequent regime was the same as in experiment I.

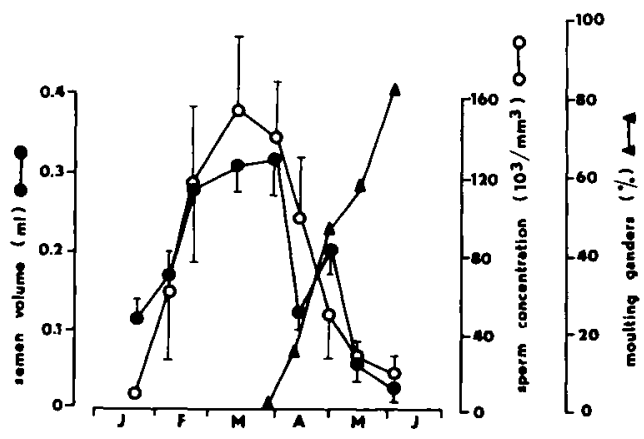

Fig 3. Changes in semen volume, sperm concentration and $\%$ of moulting ganders. Values of sperm are $M \pm \mathrm{SEM}, n=30$. 
A more precise relationship between hormone levels and primary moult was found when the hormone concentrations (from periodical samplings) were arranged according to the actual stages of the primary moult and regrowth (fig 4). Plasma testosterone concentrations were low in all sets $(<3 \mathrm{nmol} / \mathrm{l})$, ie from ganders 1 week before the primary moult to ganders with fully-renewed primaries with no significant differences among these groups. Initial stages of primary replacement (stages 37) were characterized by decreased plas$\mathrm{ma} \mathrm{T}_{4}$ levels, but these increased again to initial values during the final stages of primary growth. Low plasma $T_{3}$ levels were found in ganders at the beginning and at the termination of primary moult. Significantly $(P<0.01)$ increased $T_{3}$ levels were measured in stages $3-7$ of primary regrowth.

\section{DISCUSSION}

The absolute levels and biphasic pattern of plasma testosterone concentrations found during the annual cycle in ganders correspond with our previous results (Košutzký et al, 1982, 1984) and with those of Péczely et al (1985). These findings suggest the existence of an inherent biphasic testicular cycle profile in ganders, as already found in extensive studies of hormonal changes during the sexual cycle in drakes (Jallageas and Assenmacher, 1974; Balthazart and Hendrick, 1976; Paulke and Haase, 1978).

The peak in plasma $T$ concentration in experiment 1 was already determined in December, ie before the photoperiod was artificially increased. Moreover, high testis weight was found in ganders kept under

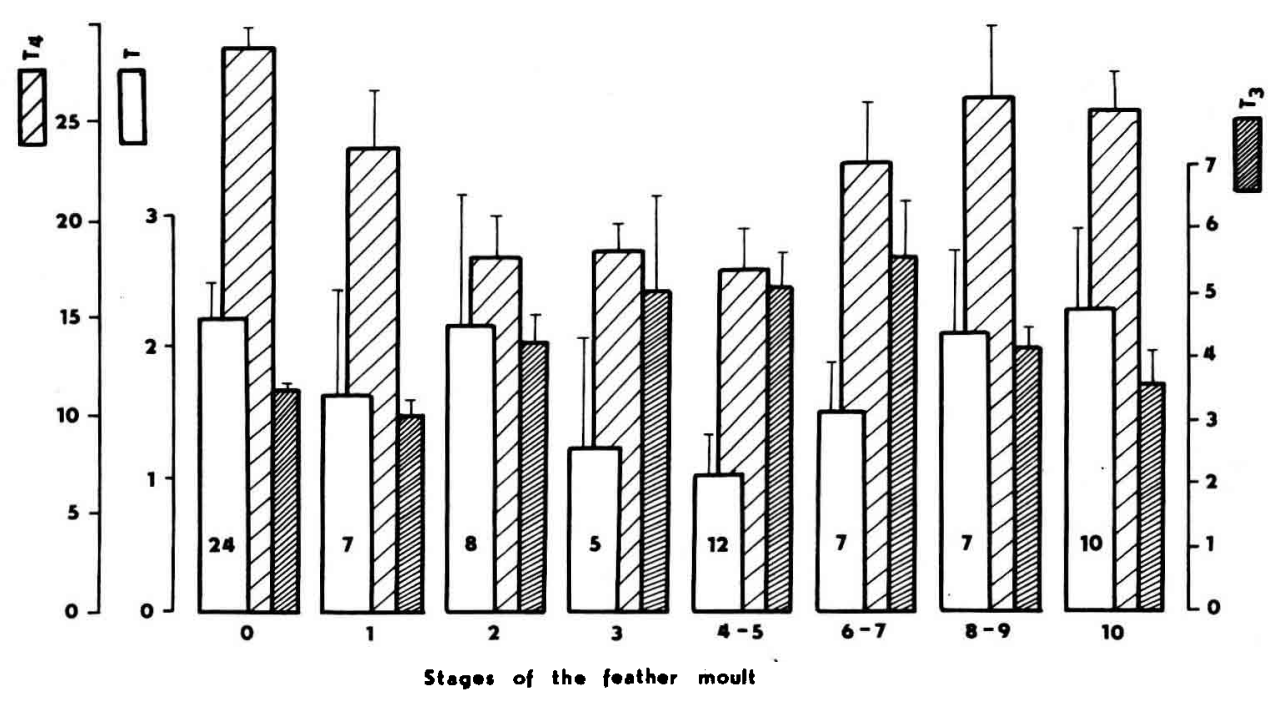

Fig 4. Plasma concentrations of testosterone, thyroxine and triodothyronine $(M \pm S E M)$ in relation to the growth stages of remiges in ganders. Remiges scoring according to Herremans (1986): $0=$ old, $1=$ dropped, $2=$ pin, 3 = brush, 4-10 represent tenths of the full-grown length. Remiges scoring is indicated on abscissa, number of hormone samples is shown in columns. 
the same lighting regime in January ( $\mathrm{Ze}$ man et al, 1987). Both these findings suggest that the photoperiod LD 8:16 was sufficient for the development of gonads at this phase of the gander's annual cycle, as found in some wild birds (Gwinner and Gänshirt, 1982; Sharp et al, 1986b). Owing to less frequent blood sampling it is impossible to determine whether the $T$ peak in experiment $\|$ occurred before or after the beginning of the day length increase. Nevertheless, it was not found exactly at the same time of year as in experiment I. We suppose that sexual development is initiated after termination of photorefractoriness. Applied photoperiod and other environmental conditions together with the age of the birds, their previous life history and nutrition determine the rate of subsequent sexual development as well as the onset and duration of the reproductive period. Therefore, a variation in these factors may account for differences in the exact timing of the reproductive cycle in different years. On the other hand, a modification of environmental conditions and nutrition may be a way of controlling the temporal pattern of the annual reproductive cycle in goose farming.

The second peak in plasma $T$ is accompanied by the second, autumnal, reproductive period in the annual reproductive cycle of ganders and the second egg-laying period in geese (Grom, 1971; Lazar, 1983); this is not observed in wild birds. The annual profile of testosterone differs partly from that found under a natural photoperiod (Košutzký et al, 1982; Péczely et al, 1985) by its peak amplitude and duration of high plasma $T$ levels. One of the reasons for a relatively short duration of high peak levels could be the fact that the ganders were kept without females. High $T$ levels in males during the egg-laying stage are stimulated by sexual behavior of females in some species of passerines
(Moore, 1982; Wingfield et al, 1989) and also in ganders (Rosinski, 1989; personal communication).

Semen volume and sperm concentration were found to be highly variable and their range corresponded with our previous results (Zeman et al, 1985). There was a phase-shift between annual rhythms in semen output and plasma $T$ concentration. Maximum sperm output was preceded by maximum plasma $T$ levels in both vernal and autumnal reproductive periods. During vernal reproductive season culmination (March-April), plasma T levels represented only $30-40 \%$ of the peak values determined in January and February. Mean testis weight in April represented approximately $50 \%$ and in May $20 \%$ of the maximum testis weight found in February (Zeman et al, 1987). These results show that in spite of the decrease in plasma $T$ levels, viable spermatozoa were produced by ganders for 3-4 months afterwards. The high plasma $\mathrm{T}$ levels seem to correspond to behavioral activities occurring at the beginning of the reproductive period in water-fowl (aggressive behavior, formation of pairs, territorial defense) rather than to the process of spermiogenesis. The local mechanisms in seminiferous tubules were probably sufficient for maintaining the intratubular androgen concentrations essential for normal spermatogenesis in mammals (see Amann, 1983 for a review) and probably also in birds (Sharp et al, 1977) in spite of low $\mathrm{T}$ levels in peripheral circulation.

Plasma $T_{3}$ and $T_{4}$ levels in ganders (2.7-9.7 nmol// and 22.1-36.4 nmol// resp) were similar to those reported for other species of Anseriformes (Jallageas et al, 1978; John and George, 1978; Campbell and Leatherland, 1980) and for immature domestic geese (Lazar et al, 1981). The role of the thyroid gland in the development of long day refractoriness (Dawson, 
1984; Nicholls et al, 1984) and in the periodic replacement of plumage in birds (see Payne, 1972, for review) has been suggested. An involvement of sex and thyroid hormones in the control of moult was established largely in studies using pharmacological doses of exogenous hormone administration (Payne, 1972). Moreover, significant correlations between spontaneous changes in plasma sex and thyroid hormones and the feather moult were found in Barheaded geese (Dittami and Hall, 1983) and in laying hens (Herremans et al, 1988; 1989). In our experiment, the increase in plasma $\mathrm{T}_{4}$ levels was recorded from midFebruary to mid-March, ie during the period of a marked drop of plasma $T$ levels, and remained high throughout the breeding season. In mallards, plasma $\mathrm{T}_{4}$ also begins to increase after plasma $T$ levels fall (Haase and Paulke, 1980; Sharp et al, 1986a). Increased levels of plasma $T_{4}$ found during the breeding season are in accordance with findings in Canadian geese (John and Georg, 1978) and indicate an involvement of the thyroid gland in the control of metabolic processes and overall activity connected with reproduction. The peak in plasma $\mathrm{T}_{3}$ may be associated rather with the low temperature prevailing during this period.

Because no clear relationship between plasma levels of $T, T_{3}, T_{4}$ and remex moult was evident on a temporal basis, this relationship was analyzed by relating hormone concentrations to individual stages of remex moult. By this approach low plasma $T$ levels were revealed at all stages of primary moult and regrowth. This finding corresponds with the classical antimoult role of testosterone (Payne, 1972) and suggests that the decrease of circulating androgen levels is a prerequisite to the onset of feather moult. This result physiologically parallels the drops in progesterone, necessary to induce moulting in laying hens as documented by Herremans et al (1988, 1989). The lowest $T_{4}$ levels were found in ganders during the regrowth of primaries (stages 3-7), when plasma $T_{3}$ levels were increased. On the other hand, high plasma $\mathrm{T}_{4}$ levels and low $\mathrm{T}_{3}$ concentrations were found before the moult and again during the final stages of primary replacement (stages 8-10). This inverse relationship clearly suggests that the rate of peripheral conversion of $T_{4}$ to $T_{3}$ may be important for feather growth.

\section{ACKNOWLEDGMENTS}

We thank $E$ Decuypere and $M$ Herremans for valuable comments concerning the manuscript.

\section{REFERENCES}

Abraham GE (1977) Handbook of Radioimmunoassay. Marcel Dekker, New York, pp 611

Amann RP (1983) Endocrine changes associated with onset of spermatogenesis in Holstein bulls. J Dairy Sci 66, 2606-2622

Assenmacher I, Jallageas M (1980) Circadian and circannual hormonal rhythms. In: Avian Endocrinology (Epple A, Stetson M, eds) Academic Press, New York, 391-411

Balthazart J, Hendrick J (1976) Annual variation in reproductive behaviour, testosterone and plasma FSH levels in the Rouen duck, Anas platyrhynchos. Gen Comp Endocrinol 28, 171-183

Campbell R, Leatherland J (1980) Seasonal changes in thyroid activity in the lesser snow goose. Can J Zool 58, 1144-1150

Dawson A (1984) Changes in plasma thyroxine concentration in male and female starlings (Sturnus vulgaris) during a photoinduced gonadal cycle. Gen Comp Endocrinol 56, 193-197

Dawson A (1989) The involvement of thyroxine and daylength in the development of photorefractoriness in European starlings. J Exp Zool 249, 68-75 
Dittami JP, Hall MR (1983) Molt, $T_{4}$ and testosterone in adult male and female Barheaded geese Anser indicus. Can J Zool 61, 26952697

Farner DS, Gwinner E (1980) Photoperiodicity, circannual and reproductive cycles. In: Avian Endocrinology (Epple A, Stetson MH, eds) Academic Press, New York, pp 331-336

Farner DS, Wingfield JC (1980) Reproductive endocrinology of birds. Ann Rev Physiol 42, 457-472

Follett BK, Nicholls TJ (1984) Photorefractoriness in Japanese quail: possible involvement of the thyroid gland. J Exp Zool 232, 573-580

Grom A (1971) Geese breeding. In: Poultry Breeding (Rous K, ed) SPN Prague, 271-306 (in Slovak)

Gwinner E, Gänshirt G (1982) Testicular development in European starling in early spring. Response to short or increasing day length? Naturwissenschaften 69, 555-557

Herremans $M$ (1986) A new method of recording moulting in the fowl. Br Poult Sci 27, 177193

Herremans $M$, Decuypere $E$, Chiasson RB (1988) Role of ovarian steroids in the control of moult induction in laying fowls. $B r$ Poult Sci 29, 125-136

Herremans M, Verheyen G, Decuypere E (1989) Some data on moulting and its hormonal context in dwarf broiler breeders. Arch Geflüegelkd 53, 196-203

Haase E, Paulke E (1980) Concentration of triiodothyronine, thyroxine and testosterone during the annual cycle of wild mallard drakes and the effects of thyroidectomy. Zool Anz Jena 204, 102-110

Jallageas $M$, Assenmacher I (1974) Thyroid gonadal interactions in the male domestic duck in relationship with sexual cycles. Gen Comp Endocrinol 22, 13-20

Jallageas M, Tamisier A, Assenmacher I (1978) A comparative study of the annual cycles in sexual and thyroid function in male Peking duck (Anas platyrhynchos) and teal (Anas crecca). Gen Comp Endocrinol 36, 201-210

John T, George JC (1978) Circulating levels of thyroxine $\left(\mathrm{T}_{4}\right)$ and triiodothyronine $\left(\mathrm{T}_{3}\right)$ in the migrating Canada goose. Physiol Zool 51, 361-376
Košutzký J, Bobáková E, Zeman M, Śárniková $B$ (1982) Plasma testosterone levels in ganders during reproductive season. Živoč Výr 27, $695-700$ (in Slovak)

Košutzký J, Bobáková E, Zeman M, Miček L (1984) The relationship between reproductive performance and plasma testosterone levels in ganders. Proc 17th World Poultry Congr, Helsinki, 37-38

Lazar V (1983) Biological phases in reproductive cycle of geese. Folia Univ Agric (Brno), Fac Agron, 1-76 (in Czech)

Lazar V, Pícha J, Píchová V (1981) Plasma testosterone, estradiol, progesterone and thyroxine concentration in the course of goose rearing. Sci Agric Bohemoslov 13, 221-230

Moore MC (1982) Effect of female sexual displays on the endocrine physiology and behavior of male white-crowned sparrows (Zonotrichia leveophrys). J Zool (Lond) A199, 137-148

Nicholls TJ, Goldsmith AR, Dawson A (1984) Photorefractoriness in European starlings: associated hypothalamic changes and the involvement of thyroid hormones and prolactin. $J$ Exp Zool 232, 567-572

Nicholls TJ, Goldsmith AR, Dawson A (1988) Photorefractoriness in birds and comparison with mammals. Physiol Rev 68, 133-175

Paulke E, Haase E (1978) A comparison of seasonal changes in the concentration of androgens in the peripheral blood of wild and domestic ducks. Gen Comp Endocrinol 34, 381390

Payne B (1972) Mechanisms and control of moult. In: Avian Biology (Farner DS, King JR, eds), Academic Press, London, pp 103-155

Péczely P, Czifra G, Seprödi A, Teplán I (1985) Effect of low light intensity on testicular function in photorefractory domestic ganders. Gen Comp Endocrinol 57, 293-300

Sharp PJ, Culbert J, Wells JW (1977) Variations in stored and plasma concentration of androgens and luteinizing hormone during sexual development in the cockerels. J Endocrinol $74,467-476$

Sharp PJ, Klandorf H, McNeilly AS (1986a) Plasma prolactin, thyroxine, triiodothyronine, testosterone and luteinizing hormone during a photoinduced reproductive cycle in mallard drakes. J Exp Zool 238, 409-413 
Sharp PJ, Massa R, Bottoni L, Lucini V, Lea RW, Dunn IC, Trocchi V (1986b) Photoperiodic and endocrine control of seasonal breeding in grey partridge (Perdix perdix). $J$ Zool (Lond) 209, 187-200

Sokal RR, Rohlf FJ (1969) Biometry. Freeman and $\mathrm{Co}$, San Francisco, pp 776

Williams J, de Reviers M (1981) Variations in the plasma levels of luteinizing hormone and androstenedione and their relationship in cockerels raised under different photoschedules. Reprod Nutr Dev 21, 1125-1135

Wingfield JC, Ronchi E, Goldsmith AR, Mayrler C (1989) Interactions of sex steroid hormones and prolactin in male and female song sparrows, Melospiza melodia. Physiol Zool 62, 11-24

Zeman $M$, Uhrín $V$, Košutzký J, Bobáková $E$ (1985) The evaluation of the development of testes in relation to ejaculate production in ganders. Živoč Výr 30, 1077-1082 (in Slovak)

Zeman M, Košutzký J, Bobáková E (1986) Testosterone concentration in seminal plasma of cooks. Br Poult Sci 27, 261-266

Zeman M, Miček Ľ, Lengyel A, Košutzký J (1987) Seasonal changes in the activities of the testes and thyroid gland of ganders in relation to egg fertility. Živoč Výr 32, 137-146 (in Slovak) 